\title{
Employers' View on Problems Related to Workforce Skills and Qualification
}

\section{Klimplová Lenka}

\begin{abstract}
The aim of this exploratory study is to reveal employers' views on problems related to workforce human capital (skills and qualification). Where do employers themselves view the core of difficulties with ensuring adequately skilled workforce? Do they assign them to technological and organizational changes (a functional concept of job-specific human capital obsolescence), or do they see these problems as a result of other circumstances, such as macro-structural conditions or institutional settings? To answer these questions selected employers in mechanical engineering and information technology sectors in the Czech Republic were interviewed. The results show that the employers see the problems: 1) on the side of workforce - insufficient abilities and skills, exaggerated demands and low motivation; 2) as inadequate capacities and capabilities of the organization itself; 3) at macro-level as institutional shortcomings in the initial educational system and social benefits system. The problems related to workforce skills and qualification cannot be, thus, interpreted only in the functionalist view as job-specific human capital obsolescence, but the formulation of the problems is significantly affected by the institutional framework.
\end{abstract}

Key words: Human capital, skills, obsolescence, employers, training, organization of production.

\section{INTRODUCTION}

Appropriately skilled workforce is a necessary precondition for companies' competitiveness in all advanced economies, including the Czech Republic. Employers, thus, encounter a problem of ensuring adequately skilled workforce for their businesses to be/stay competitive in changing markets.

Adequately skilled workforce can be defined as knowledge, skills, habits, experience or professional competencies (human capital) that are required by employers for exercises of certain professions at certain time. It is necessarily a relative category - relativity follows from the fact that the qualification requirements have changed/are changing over time. These requirements are determined by the economic-production and organizational conditions as well as by a complex of social and institutional factors (Krebs et al., 2005, p. 411). At the same time, difficulties with ensuring of skilled workforce might be understood as difficulties in providing (continuing) vocational training. These views are presented in a theoretical framework at the beginning of this paper.

But the question is: Where do employers themselves view the core of such difficulties with ensuring of adequately skilled workforce? Do they assign them to technological and organizational changes (a functional concept of job-specific human capital obsolescence), or do they see these problems as a result of other circumstances, such as macro-structural conditions or institutional settings? The aim of this paper is to answer these questions by investigating selected companies 
in mechanical engineering (hereafter ME) and information technology (hereafter IT) sectors in the Czech Republic.

The author is interested in views and opinions of managers and in their interpretation of problems related to workforce skills and qualification, therefore the qualitative research strategy was chosen. As a result, identification and understanding of different employers' view on the problem might help to explain diverse solutions of the problem as well as to reveal various expectations that employers have towards other actors and institutions at regional as well as national level.

\section{THEORETICAL FRAMEWORK}

\subsection{Functional View - Human Capital and Skills Obsolescence}

Starting with a definition of human capital, buman capital is more generally understood as knowledge, skills and abilities of people, accumulated through initial education, further education and work experience, which are useful for production of goods, services and other knowledge. Economic literature respects division of human capital into general and specific (Becker, 1975). This division is based on possibilities of using knowledge and skills at various types of companies. The general buman capital represents knowledge and skills useful in all companies and industries. Investments in this type of human capital increase the productivity of all firms. The specific buman capital represents knowledge and skills that can be used by only a few or even one employer. Investments in this type of human capital are, thus, only to increase productivity in these particular companies or company (cf. with general, sector-specific and firm-specific skills presented by EstevezAbe, Iversen and Soskice, 2001). Division of the human capital into general and specific is crucial for conceptualization of human capital (skills) obsolescence as well as for further discussion about expectations, perceived responsibilities for human capital investments and solutions of problems related to workforce skills and qualification preferred by employers.

Recent rapidly changing demands on human capital and workforce skills are the results of socio-economic changes in contemporary societies - economic globalization, international specialization, technological progress, a shift from mass production to on-demand production with emphasis on customer's individual needs, a shift from industrial manufacturing to a service economy, organizational changes (flexible forms of work organization, teamwork, a greater range of tasks within a single job), as well as population ageing (for details see Klimplová, 2010). All these changes have contributed to the acceleration of human capital obsolescence.

One can distinguish two types of human capital obsolescence - technical and economic obsolescence (de Grip, 2006, Matoušková, 2007). Technical obsolescence is associated with actual obsolescence of knowledge and skills of an individual (the process of skills depreciation caused by changes of staff themselves, i.e. deterioration of manual skills or physical strength due to ageing). Economic obsolescence concerns reductions in the market value of the qualification. More precise division of human capital obsolescence in relation to its causes is presented in the Table 1. 
Tab. 1 - Human Capital Obsolescence. Source: Based on van Loo, de Grip, and de Steur, 2001; de Grip, 2006; Matoušková, 2007

\begin{tabular}{|c|c|c|}
\hline Types of obsolescence & $\begin{array}{c}\text { Subtypes of obso- } \\
\text { lescence }\end{array}$ & $\begin{array}{c}\text { Causes of obsolescence - depre- } \\
\text { ciation of human capital by: }\end{array}$ \\
\hline \multirow{2}{*}{$\begin{array}{c}\text { Technical human capital } \\
\text { obsolescence }\end{array}$} & Wear & $\begin{array}{c}\text { Natural ageing process, illness, } \\
\text { injuries }\end{array}$ \\
\cline { 2 - 3 } & Atrophy & No or insufficient use of skills \\
\hline \multirow{2}{*}{$\begin{array}{c}\text { Economic human capital } \\
\text { obsolescence }\end{array}$} & Sector-specific & $\begin{array}{c}\text { New skill requirements due to } \\
\text { technological and organizational } \\
\text { developments }\end{array}$ \\
\cline { 2 - 3 } & $\begin{array}{c}\text { Shrinking employment in occupa- } \\
\text { tion or economic sector due to } \\
\text { unchanged demands on knowledge } \\
\text { and skills }\end{array}$ \\
\cline { 2 - 3 } & Firm-specific & $\begin{array}{c}\text { Layoffs in a company on grounds } \\
\text { of closure or restructuring (external } \\
\text { mobility) }\end{array}$ \\
\hline
\end{tabular}

Employers deal with human capital obsolescence similarly as with physical capital obsolescence - either they upgrade/update it or replace it (Matoušková, 2007). In the case of human capital it means either investments in further education, deepening and upgrading of skills, or a dismissal of an employee with insufficient knowledge and skills and hiring a new one with demanded human capital.

Ways of human capital updating should match to the type of obsolescence. As regards the first type of technical obsolescence (see Table 1) - the physical or mental wear - the best way is retraining for jobs that are not so physically or mentally demanding. Matoušková (2007), however, points out the fact that due to limited incentives to remain in the labour market, such solution is underinvested and exits from the labour market through various forms of inability schemes are preferred. As regards the second type of technical obsolescence - buman capital atrophy - the best solution is to update knowledge and skills, but only if such knowledge and skills are still demanded in the labour market. In the case they are not demanded anymore, it is necessary to acquire new knowledge and skills (Matoušková, 2007).

Job-specific buman capital obsolescence is closely linked to developments in a society. Organizational changes such as reorganization and changing system of management can significantly affect the work content and increase a risk of skills obsolescence for a specific job (van Loo, de Grip, and de Steur, 2001). Organizational changes are, in fact, often initiated by changes in a production process. Mass productions where relatively homogenous and semi-skilled workforce was demanded have been increasingly replaced by a new production paradigm where the main focus is on tailor-made products. This requires a flexible organization of production and, thus, calls for more flexible and multi-skilled workforce which is able to adapt instantly and constantly to changing working conditions (Klimplová, 2010). New technologies also often require new or different skills for the same job. An obvious example is the use of information technolo- 
gies which has changed demands on workforce skills almost in all professions (Mertaugh \& Hanushek, 2005, Planas et al., 2001; van Loo et al., 2001, etc.). Another significant trend in companies that alters skills demands is a growth of international competition (van Loo et al., 2001; Matoušková, 2007). Last but not least, demographic changes can also play a significant role. A risk of human capital obsolescence regards especially older workers who underwent their initial education many years ago and who do not participate in further education in enterprises as widely as their younger colleagues (van Loo et al., 2001; Matoušková \& Žáčková, 2008, etc.). Job specific human capital obsolescence, therefore, requires the development of company training and educational courses responsive to the changing demands on human capital.

Sector-specific human capital obsolescence occurs when employment in a particular sector disappears. There is a pressure on workers to leave and start working in another sector. However, by that they might lose a part of their human capital. This also applies to firm specific buman capital obsolescence when workers are forced to change a company as a result of production restructuring (downsizing) and subsequent dismissals. Both types of mobility (between sectors and between firms) are enforced and can cause human capital obsolescence. This obsolescence is more problematic if knowledge and skills are highly sector or firm specialized (specific human capital). Factors increasing a risk of occurrence of this obsolescence are changes in labour market demand in specific sector / industry, occupation and/or the type of education (van Loo et al., 2001). Retraining for jobs in another sector is the solution to the sector specific buman capital obsolescence. The firm specific human capital obsolescence can be addressed by completion of knowledge and skills specific to another company where one can employ current (general or sector-specific) human capital (de Grip, 2006, Matoušková, 2007).

The primary focus of the empirical study is placed on job specific buman capital obsolescence related to technological and organizational changes in companies (a functional view on social risks in organizations). Research focuses on changes in requirements on knowledge and skills of the workforce and on causes of such changes, but also on changes in abilities and skills of the workforce when human capital requirements stay unchanged (wear of human capital). The question how employers generally define and interpret problems related to workforce skills and qualification is also in focus. Are these problems viewed as related to functional changes and associated with human capital and skills obsolescence, or do employers view other causes of such problems?

\subsection{Institutional View - Different Levels}

Besides the functionalist view, one can also employ an institutional view assuming that perceptions of a problem situation may be determined by various institutions:

a) at the macro-level - there is an institutional framework of a market economy that shapes interpretations, preferences, and strategies of employers (see the Varieties of Capitalism approach, Hall \& Soskice, 2001, Hall, 1999, Soskice, 1999), and also an institutional framework of regional and local labour market is significant for the topic under discussion; such institutional frameworks, however, are hard to objectively and comprehensively conceptualize (Scharpf, 1997), therefore employers' subjective interpretation of the meanings of institutions (institutional frameworks), which according to them determine their perception, preferences, and strategies, is important; b) at the meso-level - institutions such as established organizational rules, routines, norms and 
stereotypes, but also general preferences, goals, and capabilities of the organization as a whole, shape perception of a problem situation;

c) at the micro-level - personal norms, stereotypes, preferences of an employer as well as his current "stock of knowledge" (Schütz, 1962) play an important role in his perception of a problem situation.

Both above presented theoretical approaches will be used for explanation of differences in interpretations of the problems associated with ensuring of appropriately skilled workforce.

\section{RESEARCH DESIGN}

Research was conducted within the larger research investigation entitled "Quality and Work Organization in Different Sectors of National Economy of the Czech Republic" within the research project "New social risks and the need to reform the labour market political regulation after accession of the Czech Republic to the EU. Monitoring and evaluation of needs" (2005 - 2011).

The research aim was to explore how employers subjectively perceive problems associated with ensuring that their workforce has the appropriate skills (i.e. how employers define a problem situation) and whether the interpretation of the problem situation varies depending on the modes and organization of production. Therefore two sectors were selected where it is expected that the mode of production and organization of work varies - the mechanical engineering sector and information technology sector (see below information on sampling).

The first round of interviews with representatives of 19 selected companies was carried out in spring and summer 2009 together with a survey of their employees. A topic of workforce skills was one of the three major themes of the interviews (the other topics were the role of employers in employees' social protection and employers' role in reconciling of family and work). The second round of interviews was carried out from December 2010 to February 2011. 17 of the 19 companies agreed to participate in the second round of the investigation which was primarily focused on other topics than the first round of interviews, but workforce skills and training in companies were partly included as well. Therefore these interviews were included into the analysis - this might facilitate understanding of employers and bring time dimensions (e.g. impact of economic crisis).

Companies into the research sample were selected using the stratified purposive sampling technique which depicts the characteristics of specific subgroups in the center of our interest and allows their comparison (Patton, 2002). The sample was selected based on the following criteria:

- Industry criterion - not all sectors, industries, and companies experienced a shift from Fordism to post-Fordism which fundamentally changed the requirements for workforce skills and qualification (see Klimplová, 2010, 2011) and accelerated the process of human capital obsolescence. The aim was to choose a typical example of a sector still representing the Fordist mode of production and work organization and, on contrary, a typical example of a sector representing the post-Fordist mode of production and work organization (Klimplová, 2010, Kubátová, 2004, Schienstock et al., 1999, etc.). As a typical example of a post-Fordist sector the IT sector was selected, and as the example of Fordist sector (representing the "old" method of production and work organization with a relatively stable demand for qualified labour force) the mechanical engineering sector was selected. It has been assumed that the 
ways how employers perceive and interpret problems related to workforce skills and qualification will differ in these two sectors.

- Size criterion - companies of different sizes were included into the sample, nonetheless a criterion was not to include companies with less than 20 employees (the number of employees in the time of the first round of interviews ranged between 24 and 280 employees).

- Region criterion - regions with different situations in the regional labour market were selected: A region with an unemployment rate more than 1 percentage point below the unemployment rate in the Czech Republic (hereafter CR), B region with an unemployment rate at an average unemployment rate in the $\mathrm{CR}( \pm 1$ percentage point), the region $\mathrm{C}$ with an unemployment rate more than 1 percentage point above the average unemployment rate in the CR in February 2009 (see MPSV, 2009).

- Last but not least selection criterion was a criterion of compliance or participation (cf. Žižlavský, 2005, Patton, 2002), i.e. willingness of companies to cooperate on research. This criterion affected the final research sample because not all of the addressed organizations were willing to take part in the research. However, the research has not aimed to be representative, but explorative - to explore the relationships between industry, organization size, respectively location and employers' interpretations of problem situations.

Research design can be described as comparative (Bryman, 2008). Different cases are compared both among themselves and between the two studied sectors (IT and mechanical engineering), based on the functionalist assumption that employers' interpretation of a problem situation with ensuring the adequately skilled labour force should be different depending on the mode of production and work organization.

Thematic analysis, namely the framework analysis, has been used as the method of data analysis. "Framework" is a method based on a matrix for ordering, synthesis and analysis of qualitative data. The thematic framework is used to classify and organize data according to key themes, concepts and emerging categories. Each study has a different theme and framework consisting of a series of major topics, further broken down into a number of related subtopics (Ritchie, Spencer, and O'Connor, 2003). The method involves five steps: 1) getting familiar with the data, 2) identifying a thematic framework (an index), 3) indexing, 4) creating thematic tables, 5) mapping and interpretation (Ritchie \& Spencer, 1994).

Under a theme "problem situation" the following subtopics have been identified: a) new technologies, products, production processes, b) population ageing, c) situation on external labour market, d) problems/shortcomings of the educational system, e) skills and abilities of workforce, $f$ ) motivation and demands of workforce, g) changes related to economic crisis, h) others (Klimplová, 2011). The results of the last stage of thematic analysis (mapping and interpretation of data) which aims to understand and explain employers' perception on problems related to workforce skills and qualification are presented in the following chapter.

\section{EMPIRICAL FINDINGS}

"... the employees are our greatest capital. [...] They are the foundation of the company. Machines can be acquired easily today, but try to find people who know how to deal with them." (An employer in a ME firm with 55 employees) 
This chapter firstly focuses on qualification and other requirements the employers in mechanical engineering and IT sectors have on their workforce and, secondly, on whether and why these requirements have changed over time. Thirdly, different employers' views on problems related to workforce skills and qualification will be presented.

\subsection{Employers requirements on human capital of their employees}

Not surprisingly, the requirements on workforce human capital differ considerably in both studied sectors. It depends, of course, on an occupational position of a particular employee, but if we look at workers that employers consider as key employees, then the employers in the mechanical engineering industry talk about professional qualifications - professions as welders, locksmiths, metal machinists, milling machine operators, CNC machine operators, etc. in the case of manual workers, and constructors, technologists, quality engineers, etc. A specific case was a company producing lift components and reconstructing lifts which demanded special electro-technical education because due to technological advances a trained locksmith cannot anymore do the required work (see also the next sub chapter). However, it is important to point out that these workers, though well-qualified, are becoming key employees only after induction training on technologies used in a specific company (specific buman capital). After that they are becoming the bearers of know-how and production processes.

Not only very specific professional qualification, experience and professional skills (e. g. reading from technical drawings) are required by the ME employers, but also certain personal characteristics (especially responsibility, reliability). Companies displaying features of post Fordist production methods and work organization (on-demand production with emphasis on customer's individual needs, product diversity, accelerating innovations, etc., more in Schienstock et al., 1999, Klimplová, 2010) also require employees' ability to adapt quickly to changing conditions (i.e. flexibility, creativity, innovativeness).

Demands of the employers in the IT sector differ. The requirements are not as clearly specified in the terms of formally acquired qualifications (university diploma or secondary education in a certain field, etc.) or professions, but rather they are presented as a set of desired personal qualities and professional abilities and skills, such as reliability, loyalty, politeness, flexibility, the ability to solve problems and respond to newly-emerged situations, communication skills, the ability to work with other people, the ability to manage people (for managers), an active approach, the ability and willingness to learn new things (all these can be labelled as soft skills, or as a general human capital).

Above presented differences in requirements on key workforce also determine different employers' interpretations of problems related to workforce skills and qualification. To facilitate understanding of such different interpretations, the author firstly presents employers' views on changes in skills requirements over time.

\subsection{Changes in human capital requirements over time}

The results of a quantitative survey among employees in the studied organizations show that 65 $\%$ of employees in the ME sector and $63 \%$ of employees in the IT sector think that qualification and skills requirements have increased over time. Based on the functional assumptions, one would expect that changes in requirements (which imply a potential risk of human capital 
obsolescence) will be more acute in the IT sector; however, the results show that employees in the both surveyed sectors are under pressure to update their knowledge and skills. Based on qualitative interviews with employers, two causes can be identified: 1) technological and organizational changes within organizations, 2) external environment changes. These causes are elaborated below in detail.

1) Technological and organizational changes within organizations: Technological progress is the main cause of changes in human capital requirements. Demands have been increasing, that can be labelled as upskilling (Brandsma, 2001). The signs of technological advances can be identified in the both studied sectors, nonetheless, the changes are much more pronounced in the IT companies (a rapid change of programming platforms brings about the need for instant updating of knowledge and skills).

In the case of the ME sector, the changes in requirements caused by technological advances were identified only in certain cases. Although (robotic) automation could be seen as deskilling, i.e. situations where new technologies contribute to such production automation that it is possible to delegate certain production tasks to low-skilled workers (Planas et al., 2001), our results show the real opposite. Automation and robotics in production bring about higher demands on machine operators - workers do not only operate the machine, but they must also be able to program it. Another example is the abovementioned lift company which has completely changed the qualification and skills requirements - from the locksmith profession toward electro-technical education. Qualification requirements, thus, have been increasing due to technological advances which bring about job-specific human capital obsolescence.

Some ME firms also shows a change in production paradigm - from mass production towards "tailored" production - accompanied by increasing demands on workforce abilities and skills (in particular, flexibility, creativity, innovativeness, ability to solve a specific problem). This shift can be seen as an attempt to adapt to the new conditions via finding new markets (offering individual solutions and "tailored" products to satisfy individual customers). The IT companies, in addition to solutions "tailored" for an individual client, also show increasing demands on flexible and multi skilled workers due to specific new projects and orders requiring variability of solutions (see also the interview extract below).

The production paradigm shift towards satisfying wishes of individual clients and on-demand productions have also increased requirements for accuracy, thoroughness, and quality of orders execution. There is also a noticeable impact of the introduction of ISO norms (www.iso.org) in some enterprises which normatively determine "needs" for further education to be in line with these quality standards.

2) External environment changes: In addition to changes in customer demands, one can also identify changes of customer's abilities to work with certain products as a cause of increased requirements on workforce skills. The following extract from an interview aptly describes this change:

"[Requirements] are changing because the environment in which regular users work is changing and the users' level is changing in a quite staggering way as well. All Microsoft applications promote the idea that the user does not have to know anything, which is indeed nice, but from the perspective of both the users and us, as service providers, it is murderous, since we cannot get relevant information from the users on what is going on. Quite common information we get is "that little window which has always been there is not there anymore". In this sense, the requirements 
on workforce skills have changed because when a serviceman set out to a customer five years ago be knew what exactly to do there. Today he knows nothing. "(An employer in an IT firm with 42 employees)

There is a clear requirement for flexibility and responsiveness to an individual problem of a particular client, i.e. the ability to respond to newly-emerged conditions that cannot be planned in advance. Therefore multi-qualified workforce able to deal with much more complex and unpredictable problems and requirements of customers is needed.

Besides technological advances and changes in the production paradigm, changes in legislative norms are pressing on adaptation or up-dating of knowledge and skills. Firstly, there are certain regulations on professional competences and regular continuing vocational training and re-examination of employees in the ME industry (e.g. welder exams must be repeated after a certain time). Normatively given requirements for further training and re examination apply, however, to employees in all sectors (including the both studied sectors). For instance, there are regular drivers' training courses or courses on legal and other regulations to ensure the safety and health at work, including regular verifications of such knowledge (see the Labour Code of the Czech Republic, \133, paragraph 1).

Secondly, the frequent changes of laws and regulations necessitate updating of knowledge and skills in the field. Areas of (payroll) accounting (e.g. changes in tax laws, in health insurance law, etc.) or areas of personnel management (changes in the Labour Code, etc.) are most frequently stated. These laws amendments and the associated need for updating of knowledge are - unlike the above normatively given regular further training and examination - unpredictable. Employers cannot plan ahead when politicians change the laws and when there will be a need to re-train people accordingly. Unpredictability of such situations and especially the frequency of such changes are interpreted by some employers as a problem.

\subsection{Employers' views on problems related to workforce skills and qualification}

The interviewed employers define and interpret the causes of problems related to the lack of workforce skills (human capital) in several different ways. Firstly, they see the causes of such problems on the side of workforce (in their abilities and skills, but also in their demands and motivation). Secondly, causes are perceived as different limits on the level of an organization. Finally, one can speak about the causes at the macro-level, such as a situation in a regional labour market, shortcomings in an initial education system or workforce ageing. These different views are presented in a broader context below and possible solutions to these problems as perceived by the employers are shown. The author aims to depict cause-effect relationships - the employers' responses to what they consider to be the cause of the problem - and also present expectations of employers towards other actors and institutions when ensuring the adequately skilled workforce.

1) Causes on the workforce side: a) Lack of skills and abilities of workforce: First of all, there is a problem of employees to adapt to changing conditions which follow from technological advances and changes in the production paradigm. The very technological advances or the introduction of new products or production processes themselves are not interpreted as a problem. They become the problem when the current employees are not able to adapt to these changes. The employers speak about a necessity or need for adaptation rather than about a problem associated with new technologies and products. There are various solutions: a lay-off of an employee which 
is really unable to adapt and hiring a new one, re organization of work in the company, but the most common solution is training and education to help employees adapt to new technologies and products. Secondly, there is a problem of lack of managerial skills and knowledge of human resource management. Interestingly, this problem appears even in the ME companies with the Fordist production methods and work organization (standardized and formalized production without the need for specific company training of key workers). Thirdly, there is a problem of insufficient language skills of employees and job applicants, especially in companies with foreign owners or in companies with foreign customers. While this problem has been mostly interpreted as a shortcoming on the side of workforce, a view that causes of this problem lies within the initial education system has appeared too. The language courses in organizations as a response to this problem play a specific role, because on the one hand they are seen as a necessity, on the other hand, they are often presented as benefits for employees.

b) Low motivation and exaggerated demands of the workforce: The problem has been defined by employers in the ME industry as a lack of interest in the branch, in the occupation among young people. In employers' view, people do not want to work with their hands, though craft work can often be better paid than an office work. According to the employers, there is a lack of awareness about the ME industry among people, they are not well informed how the field has transformed in the recent years - new technologies (digital/computer-controlled machines) and content of the work. Young people are not particularly motivated to go to the requested apprenticeships. In this regard, the problem is seen not only as a mistake on the side of individuals, but also as a system error (settings of the initial education system and an institutionally weak support of the ME fields) which raises the expectations of employers that this error should be somehow systemically (at national or regional level) resolved (see below).

Furthermore, there is also an explanation of the low interest in apprenticeships as affected by contemporary social trends and media presentation of education as the only options for good career prospects. Palán $(2002,2007)$ explains this using the theory of credentialism - an overemphasis on diplomas or degrees in giving jobs or conferring social status. According to Palán, this leads to inflation of the value of educational credentials. Everyone wants to have at least a high school or university diploma, although this is often not a high quality education and its outputs do not match labour market demands or expectations of employers. However, the problem is not seen only as a lack of interest in the ME branch, but more generally as people's disinterest to be working at all. In particular, this problem relates to the unemployed, especially those with low human capital. After comparison of unemployment or social security benefits with offered wages, they are very reluctant to start working. When a person after a longer period of unemployment returns to work, he/she is viewed by employers as a burden. "The company has to teach such people work again, does not matter whether he is young or old. They have no morals, no ethics, and no responsibility." (a ME firm with 110 employees) Again, this situation is perceived not only as a problem at the individual level, but also at an institutional level in the area of employment policy, and hence the relevant solution is viewed as a change in the settings of conditions in this area.

In the IT field, the situation is specific since there are some skilled people in the labour market, but their demands are exaggerated or sometimes even unrealistic. This does not concern only salaries, but also other benefits (company car, phone, etc.). Especially the university graduates come to apply for their first jobs with "weaker knowledge but increasing self-confidence which tells them to 
ask for higher salaries" (an IT firm with 140 employees). Employers see two possible explanations of causes of this situation - for one thing it is related to the situation in the labour market when the lack of skilled people allows job-seekers to come up with such high demands, and for another, there is a significant impact of media on self perception and demands of skilled people on their appraisals.

A lack of appropriately skilled workforce allows to escalate job-seekers' demands in the ME industry too. However, employers in both sectors agree that the economic crisis has helped in this regard and due to the loss of job opportunities the job-seekers' demands have decreased as well. In the second round of the interviewing, the employers in the IT industry, however, again pointed out the increasing demands by job-seekers due to the industry recovery. It is evident that the macro economic situation has had a significant impact on the employers' view of the problem.

The above-mentioned views of problem situations (people's disinterest in the ME branch, people's disinterest in work generally, unreasonable demands) are associated with the job seekers. Employers, however, view the problem on the side of their employees too - and that is the lack of interest in further education. This was partly presented in the previous section, but it is not just about abilities to adapt to changing conditions, but also about the motivation and interest to do so (in the form of further education) which some employers perceive as a problem. Some employers in this context talk even about an employee burnout syndrome. The solution is often a leave of that worker, or - in the case of an employee which a company does not want to lose - work reorganization in order to motivate him/her by another form of work.

2) Limits on the level of an organization: This view of the problem is partly related to previous points. On the one hand, there are high demands of job applicants regarding remuneration and other benefits; on the other hand, there are limited possibilities of a number of companies in the ME as well as IT sector to meet these requirements. In such a situation, the problem is viewed not only in regards to job-seekers, but also to current employees who might be offered better (especially salary) conditions and poached by a rival company. Other limits on the level of the organization are financial and time constraints on investments in further company education (Klimplová, 2012).

3) Macro-structural and institutional causes: a) Workforce ageing: Population ageing - the emerging trend in all European countries - is significantly accentuated by employers in the ME sector (it does not appear in the IT sector at all), although it is perceived more as a risk in near future than as a current problem. In one, two decades generations of skilled workers will go into retirement and there will be a big problem to replace them due to the lack of graduates in demanded apprenticeships. Such a view of a possible future problem supports the theoretical assumption that the production mode in the ME sector is Fordist - workers (mostly skilled bluecollar workers) stay throughout their long-life career in one job, replacement of workers usually occurs only due to retirement leaves and there is an effort to hire already skilled workforce without the need for large investments into further training and education in a company (except for regular obligatory refresher courses and re-exams in the case of certain professions, see above). So employers expect "generation replacement" in about one, two decades, however, they fear there will be nobody to replace leaving workers. 
b) Institutional shortcomings in the initial education system: The above-described concerns are closely related to the following phenomena. Firstly, there are low requirements for admission to mechanical secondary schools and high schools as well as questionable quality of many private secondary schools and universities. Due to the smaller number of children schools compete for attendees and try to attract them by lowering the admission requirements as well as lowering demands during the studies. That results in a general lack of apprentices because young people generally prefer further education at secondary schools or high schools than apprenticeships (see above the theory of credentialism, Palán, 2007). Educational certificates, then, no longer indicate the true value of education and employers cease to rely on their information value ("To have a diploma today, what does it actually say?"). All these imply there is no simple solution to this problem, but it must be resolved systematically (changes in institutional settings of the initial education system) in cooperation with the different actors at the regional as well as national level.

Secondly, some apprenticeships (blacksmith and lift branches in the sample) which were previously commonly taught are not offered at schools anymore. It is not very clear whether these apprenticeship fields were cancelled due to the lack of interest among young people to study in these branches or whether there were other reasons. Nonetheless, this problem cannot be resolved by employers themselves, but again other relevant actors (schools and their founders, and also other companies and professional organizations in the industry) must be involved and cooperate to find reasonable solutions.

Thirdly, there is a problem with low employability of knowledge and skills acquired at schools in practice, or the graduates' inability to apply the acquired knowledge in practice, which is caused by a low level of cooperation and connectedness between educational institutions and businesses, and in case of mechanical engineering also by outdated school equipments (the apprentices/students learn the technologies that are obsolete). This problem has been accentuated by employers in both sectors (and not only in the ME as the previous two points), and again it is clear that such a view on the problem determines employers' decisions about options for resolving the problem - start up or deepen cooperation with schools.

c) The situation in a regional labour market: The consequences of the institutional shortcomings in the initial education system presented above are obvious - a lack of specific professions/skills (welders, locksmiths, metal machine operators, etc.) in all regional labour markets where the research was conducted. In addition to weaknesses in the educational system, the lack of qualified people in the external labour market is also associated with the motivation and interest of people in working in the field (see above) and in the case of small and medium-sized ME companies also with the inability to compete for skilled workforce with large companies, which are - according to the employers of small and medium-sized enterprises - able to offer better pay and working conditions and thus to get them (i.e. related to the organizational capacity to solve the problem). In the IT industry, there is a shortage of highly skilled workforce (especially programmers and IT developers) in the external labour market as a result of strong competition between firms and poaching of employees. But it is necessary to emphasize that this does not mean a shortage of people with the appropriate university diploma, but rather a lack of people with certain desired qualities (creativity, activity, etc., see above) and with the potential for further development of human capital. On the contrary, to get some other professions (typically mentioned professions are an accountant or a secretary) is not perceived as a problem in either of the two surveyed 
sectors. So it depends on the availability of workforce with the required qualifications, respectively with the required human capital (including the required qualities) in an external regional labour market.

Aside from the shortage of qualified people, there is also a problem with a lack of job-seekers in general (not just job-seekers of certain professions) in regions with the low unemployment rates. This limits the possibility of employers to hire unskilled workforce, or people with different qualifications than required, and retrain them. Retraining as a solution of the problem with a lack of skilled workforce can only be implemented in regions with higher unemployment rate, where there are people available in the regional labour market. In regions with low unemployment rate, such low rate has been interpreted as a problem (nobody to be retrained) which is among other things related to a generally low level of horizontal mobility (people are not used and willing to move because of the work into other regions).

It should be noted that according to the employers the economic recession culminating in 2009, when the first round of interviews took place, had a positive impact on the presented structural problems of regional labour markets. In a time of economic crisis, employers could choose among higher skilled job applicants (situation caused by reduced production and subsequent lay-offs in some competing firms), and thus they could increase their demands on the required human capital. So the economic cycle determines the relative bargaining power of different actors - in a period of economic recession, employers have a stronger bargaining position, and on the other side, in the period of economic recovery, skilled workforce may escalate their requirements. Although the situation in the period of economic recession seemed to be better for employers since the offer of skilled job applicants had risen, some companies (especially in the ME sector) had no need or opportunity to hire new employees because they themselves were negatively affected by the effects of the economic recession. A lack of orders even caused some layoffs.

The second round of interviews at the turn of 2010/2011 revealed a gradual loss of IT skilled workforce available in regional labour markets due to the economic recovery and employers had to start again addressing the problem of a shortage of demanded skills.

\section{CONCLUSIONS}

This exploratory study presented different employers' views on problems related to workforce human capital (skills and qualification). To sum it up, employers see the problems: 1) On the side of workforce - insufficient abilities and skills (mainly determined by changing skills requirements as a result of technological advances and changes in production methods and work organization), exaggerated demands and low motivation. Motivation is seen as a personality trait which is, however, strongly determined by the institutional settings (in this case the system of social benefits) in which a person makes decisions. 2) Capacities and capabilities of the organization itself - financial and time constraints. 3) Causes at the macro level - structural problems of regional labour markets caused chiefly by institutional weaknesses in the initial education system and by the population ageing (perceived only by employers in the ME sector). The problems related to workforce skills and qualification cannot be, thus interpreted only in the functionalist view as job-specific human capital obsolescence (determined by technological progress and changing modes of production and work organization), but the formulation of the problems (especially by 
employers in the mechanical engineering sector) is significantly affected by institutional conditions (settings of the initial education system, unemployment benefits and social security system determining motivation of the unemployed to work, etc.). The institutional framework is thus significant for explanation of different views on problems related to workforce skills and qualification in different sectors.

The current institutional framework of initial education, in particular apprenticeships, but also secondary and higher education, is viewed by employers in the mechanical engineering sector as problematic. Due to the lack of people in certain ME branches, employers suggest conducting skills need analysis in enterprises and adapting the initial education according to these demands, e.g. reopening of the branches where there is a lack of apprentices in the labour market or supporting branches demanded in the labour market by extra subsidies. Furthermore, employers in the ME sector call for greater promotion of the industry in order to increase people's awareness of the work content in this field. They also want to raise motivation of young people to study these fields, for instance, via special forms of scholarships. They do not necessarily demand such scholarships to be paid from the state or regional budgets; they are prepared to invest in education of their potential workers, however, they miss a clear legislative framework for such solution (scholarships paid by enterprises). Can scholarships be included into the cost items? Is it possible to make a student committed to stay in the company after finishing his/her studies which were supported by scholarships paid by the company? At the time when an employer begins to support his/her studies by scholarships, a student is underage, and thus ineligible to legal acts, including signing of contracts, therefore all contracts would have to be signed by his/her parents. But how to guarantee that when a young person reaches legal age, he/she will take over all obligations which arise from a contract on provision of scholarship? Answers to these and other questions related to the provision of scholarships are ambiguous and unresolved in the view of employers in the ME sector. That limits employers' efforts to get engaged. They see scholarships as investments in the education of their future employees with the expected return and interest of such investments. Within the current institutional framework, however, risks associated with the fact that such investments might not return are perceived as too high.

Employers would also welcome changes in the content of initial education leading to greater connection of the education with practise (such view appears in both interviewed sectors), i.e. to ensure greater interconnectedness of the curriculum with the labour market needs that knowledge and skills acquired through the formal educational system are applicable in practice. This is also related to the institutional support of students' internships and support of the integration of graduates into companies. Employers perceive as a problem that it is financially more beneficial for students in some fields to do summer jobs in e.g. supermarkets than having internships in the field of their studies. Employers call for greater institutional support for students and businesses taking students on internships, but at the same time, they see also themselves as important actors in this regard.

Another problem of the initial education system accentuated by employers is the declining quality of such education as the competition among schools has risen due to the lack of children. Secondary and higher education is now more available even for young people who would not have been accepted due to their insufficient school results (or general learning inability) few years ago. The quality of the initial education should be more controlled. Employers welcome efforts 
to standardized outputs, e.g. in the form of state secondary school-leaving examinations which facilitate decision-making in hiring of new graduates (it allows for valid comparison between job applicants).

There are differences in capabilities of companies to address presented problems related to workforce skills and qualification. If the problem has been viewed as job-specific human capital obsolescence caused by technological and organizational changes or changes in legislations, and it can be addressed by further education in companies, then employers are ready to take full responsibility for solutions of such problem as company education is perceived as a necessity for fulfilment of organizational objectives - the competitiveness and higher profits. ("If we did not educate them [the employees], then we would not have orders. If we did not have orders, we would not be here anymore." - an IT firm with 110 employees) However, if the problem is interpreted in terms of institutional shortcomings in the initial education system and/or social security system, then employers call for institutional solutions (changes in settings of certain legislative and institutional rules) which requires involvement and cooperation of different sets of actors (political representation, educational institutions, professional organizations, other companies, etc.). This view is chiefly predominant in the mechanical engineering sector. Without such changes, a considerable shortage of skilled people looms large in near future which may negatively impact competitiveness of the Czech mechanical engineering sector as whole.

\section{References}

1. Becker, G. S. (1975). Human Capital. A Theoretical and Empirical Analysis, with Special Reference to Education. Chicago: The University of Chicago Press.

2. Brandsma, J. (2001). Training and employment perspectives for lower qualified people. In: Descy, P., Tessaring, M. (eds.). Training in Europe. Second report on vocational training research in Europe 2000: background report. Vol. 3 (pp. 173-206). Cedefop Reference series. Luxembourg: European Communities.

3. Bryman, A. (2008). Social Research Methods. Oxford: Oxford University Press.

4. De Grip, A. (2006). Evaluating Human Capital Obsolescence. Paper prepared for ECOECD Seminar on Human Capital and Labour Market Performance in Brussels, December 2004. Maastricht: Maastricht University. Retrieved from: http://arno.unimaas.nl/show. cgi? fid $=4650$

5. Hall, P. (1999). The Political Economy of Europe in an Era of Interdependence. In: Kitschelt, H., Lange, P., Marks, G., Stephens, J. D. (eds.): Continuity and Change in Contemporary Capitalism (pp. 135-163). Cambridge: Cambridge University Press. http://dx.doi. org/10.1017/CBO9781139175050.013

6. Hall, P. \& Soskice, D. (eds.). (2001). Varieties of Capitalism: The Institutional Foundations of Comparative Advantage. New York: Oxford University Press. http://dx.doi.org/10.1093/0199 247757.003.0001

7. Estevez-Abe, M., \& Iversen, T. \& Soskice, D. (2001). Social Protection and the Formation of Skills: A Reinterpretation of the Welfare State. In: Hall, P., \& Soskice, D.: Varieties of Capitalism: The Institutional Foundations of Comparative Advantage (pp. 145-183). New York: Oxford University Press. http://dx.doi.org/10.1093/0199247757.003.0006 
8. Klimplová, L. (2010). Lidský kapitál a factory vyvolávající změny v nárocích na něj na soudobých trzích práce. Scientia et Societas, VI/1, 91-110.

9. Klimplová, L. (2011). Zamèstnavatelé a kvalifikace pracovní síly. Disertační práce. Brno: FSS MU.

10. Klimplová, L. (2012). Rozhodování zaměstnavatelů o dalším vzdělávání zaměstnanců ve vybraných podnicích ve strojírenském a IT odvětví. Scientia et Societas, VIII/3, 167-190.

11. Krebs, V. et al. (2005). Sociální politika. Praha: ASPI.

12. Kubátová, J. (2004). Význam lidského kapitálu v postindustriální společnosti. Acta Universitatis Palackianae Olomucensis, Politoligica 3, 9-28.

13. Matoušková, Z. (2007). Představuje lidský kapitál konkurenční výhodu České republiky? Politická ekonomie, 3, 374-398.

14. Matoušková, Z. \& Žáčková, H. (2008). Angažovanost podnikư ve vžělávání zaměstnanců. Working Paper NOZV-NVF č. 3/2008. Praha: Národní observatoř zaměstnanosti a vzdělávání.

15. Mertaugh, M. \& Hanushek, E. (2005). Education and training. In: Barr, N. (ed.): Labor Market and Social Policy in Central and Eastern Europe: the Accession and Beyond (pp. 207-242). Washington: World Bank. http://dx.doi.org/10.1596/0-8213-6119-8

16. MPSV. 2009. Statistiky nezaměstnanosti z územního hlediska. Ministerstvo práce a sociálních věcí ČR. Retrieved from: http://portal.mpsv.cz/sz/stat/nz/uzem

17. Palán, Z. (2002). Lidské zdroje - Výkladový slovník. Praha: Academia.

18. Palán, Z. (2007). Dalši vždèláváni ve svètě żmèn. Praha: Univerzita Jana Amose Komenského.

19. Patton, M. Q. (2002). Qualitative Research \& Evaluation Methods. Thousand Oaks: Sage Publications

20. Planas, J. et al. (2001). The skills market: dynamics and regulation. In Descy, P., Tessaring, M. (eds.). Training in Europe. Second report on vocational training research in Europe 2000: background report. Vol. 2 (pp. 313-382). Cedefop Reference series. Luxembourg: European Communities.

21. Ritchie, J. \& Spencer, L. (1994). Qualitative data analysis for applied policy research. In: Bryman, A., \& Burgess, R. G.. (eds.): Analyzing Qualitative Data (pp. 173-194). London and New York: Routledge..http://dx.doi.org/10.4324/9780203413081_chapter_11

22. Ritchie, J. \& Spencer, L., \& O’Connor, W. (2003). Carrying out Qualitative Analysis. In: Ritchie, J.; Lewis, J. (eds.): Qualitative Research Practice. London: Sage Publications

23. Schienstock, G. \& Bechmann, G., \& Frederichs, G. (1999). Information Society, Work and the Generation of New Forms of Social Exclusion (SOWING) - the Theoretical Approach. TA-Datenbank-Nachrichten, 1(8), 3-49. Retrieved from: http://www.itas.fzk.de/deu/tadn/ $\operatorname{tadn} 991 /$ scua99a.htm

24. Schütz, A. (1962). Collected Papers. 1. The Problem of Social Reality. Ed. by M. Natanson. Series: Phaenomenologica, 11. The Hague: M. Nijhoff

25. Soskice, D. (1999). Divergent Production Regimes: Coordinated and Uncoordinated Market Economies in the 1980s and 1990s. In: Kitschelt, H. et al. (eds.): Continuity and Change in Contemporary Capitalism (pp. 101-134). Cambridge: Cambridge University Press. http://dx.doi. org/10.1017/CBO9781139175050 
26. Van Loo, J. \& de Grip, A., \& de Steur, M. (2001). Skills Obsolescence: Causes and Cures. International Journal of Manpower, 22(1/2), 121-137. http://dx.doi.org/10.1108/0143772011038 6430

27. Žižlavský, M. (2005). Metody výzkumu v sociální politice a sociální práci. Brno: FSS MU.

\section{Contact information}

Mgr. Lenka Klimplová, Ph.D., M.A.

Department of Social Policy and Social Work, Faculty of Social Studies, Masaryk University

Jostova 10,60200 Brno, Czech Republic

E-mail:klimplov@fss.muni.cz. 